\title{
A Case of Follicular Lymphoma of Sphenoid Sinus and Orbit
}

\author{
Chanhyeon Park ${ }^{1}$, Dong Hoo Lee ${ }^{1}$, Ha Young Park ${ }^{2}$, and Seong Kook Park ${ }^{1}$ (D \\ ${ }^{1}$ Departments of Otorhinolaryngology-Head and Neck Surgery, ${ }^{2}$ Pathology, Busan Paik Hospital, Inje University College of Medicine, \\ Busan, Korea
}

\author{
접형동 및 안와에서 발생한 소포성 림프종 1예 \\ 박찬현 ${ }^{1}$ - 이동후 ${ }^{1} \cdot$ 박하영 ${ }^{2} \cdot$ 박성국 ${ }^{1}$ \\ 인제대학교 의과대학 부산백병원 이비인후-두경부외과학교실, ${ }^{1}$ 병리학교실 ${ }^{2}$
}

\author{
Received December 27, 2019 \\ Revised March 25, 2020 \\ Accepted April 13, 2020 \\ Address for correspondence \\ Seong Kook Park, MD \\ Department of Otorhinolaryngology- \\ Head and Neck Surgery, \\ Busan Paik Hospital, \\ Inje University College of Medicine, \\ 75 Bokji-ro, Jin-gu, \\ Busan 47392, Korea \\ Tel $+82-51-890-6379$ \\ Fax $+82-51-892-3831$ \\ E-mail sinus4@paik.ac.kr
}

\begin{abstract}
Malignant lymphoma is a tumor of the immune system. It mainly occurs in the lymph node, but it can also originate from extranodal organs such as the gastrointestinal tract, salivary gland and the sinonasal tract. A primary malignant lymphoma in the paranasal sinuses is rare and usually occurs in the maxillary or ethmoid sinus. The sphenoid sinus is a rare primary site for extranodal lymphomas. Moreover, follicular lymphoma involving paranasal sinuses rarely occurs. Recently, we experienced a patient who complained of facial swelling, exophthalmos, reduced visual acuity, and diplopia for a month, and she was diagnosed with follicular lymphoma of the sphenoid sinus and orbit. Here we report a rare case of follicular lymphoma of the sphenoid sinus and orbit, along with a literature review.
\end{abstract}

Korean J Otorhinolaryngol-Head Neck Surg 2021;64(1):34-9

Key Words Lymphoma Orbit $\cdot$ Sphenoid sinus.

\section{서 론}

악성 림프종은 림프구에서 발생하는 악성종양으로 두경부 에서 호발하는 비상피성암 중에서 가장 흔하며, 조직병리학적 으로 크게 호지킨 림프종과 비호지킨 림프종으로 분류할 수 있다. 호지킨 림프종은 주로 비장이나 림프조직이 존재하는 부위에 국한되어 발생하나, 비호지킨 림프종은 초기에 혈류 를 통해 전이가 일어나 병기가 비교적 진행된 양상이 많다. 비 호지킨 림프종의 아형인 소포성 림프종은 $\mathrm{B}$ 세포에서 기원하 여, 성인에서 발생하는 비호지킨 림프종의 약 $1 / 3$ 정도를 차지 하는 종양으로 대부분 림프절에서 발생하며 미국에서는 가장 흔한 비호지킨 림프종의 하나이나 동양에서는 발생이 드물고 진행이 느린 암종으로 알려져 있다. ${ }^{1)}$

This is an Open Access article distributed under the terms of the Creative Commons Attribution Non-Commercial License (https://creativecommons.org/licenses/by-nc/4.0) which permits unrestricted non-commercial use, distribution, and reproduction in any medium, provided the original work is properly cited.
일반적으로 악성 림프종이 비강 및 부비동에 발생한 경우, 주로 상악동 또는 사골동을 침범하는 것으로 알려져 있으며, 국내의 경우 접형동에 발생한 T세포 림프종과 미만성 거대 $\mathrm{B}$ 세포 림프종이 각각 1 예 보고되었으나 접형동에 발생한 소포 성 림프종은 보고된 바가 없다. ${ }^{2,3)}$ 이에 저자들은 접형동 및 안와에서 발생한 소포성 림프종 1 예를 경험하였기에 이를 보 고하는 바이다.

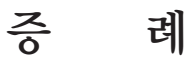

81세 여자 환자가 내원 1개월 전부터 시작된 우측 안면부 부 종 및 통증, 우안 돌출, 시력장애를 주소로 본원 안과에 내원 하였으며 자기공명촬영에서 접형동의 종물 소견이 보여 이비 인후과로 의뢰되었다. 과거력에서 만성 $\mathrm{B}$ 형간염 및 고지혈증 으로 경구 약제를 복용 중인 것 외에 특이소견은 없었으며, 체 중감소, 발열, 야간 발한 등의 전신소견은 없었다. 
안과적 검사에서 우안의 안검하수 및 시력저하를 보였으며, 양안 교정시력은 우안 0.5 , 좌안 0.8 로 측정되었고, 안구운동 검사에서 우안 내전 및 하전 제한 소견이 보였다(Fig. 1). 비내 시경검사에서 특이소견은 관찰되지 않았으며, 부비동 컴퓨터 전산화단층촬영에서 접형동 및 안와에 균일하게 조영 증강되 는 종양이 관찰되었고 안와 우측벽의 골 미란 소견이 보였다.
자기공명영상에서는 우측 안와 및 접형동 내에 $\mathrm{T} 1, \mathrm{~T} 2$ 강조영 상에서 저신호를 보이고 gadolinium으로 조영증가가 잘되 는 종양이 관찰되었으며 우측 외직근이 비대된 소견이 보였다 (Fig. 2).

접형동 및 안와를 침범한 종양을 의심하여 악성종양 및 염 증성 질환을 감별하고 치료계획을 수립하기 위해 수술적 조
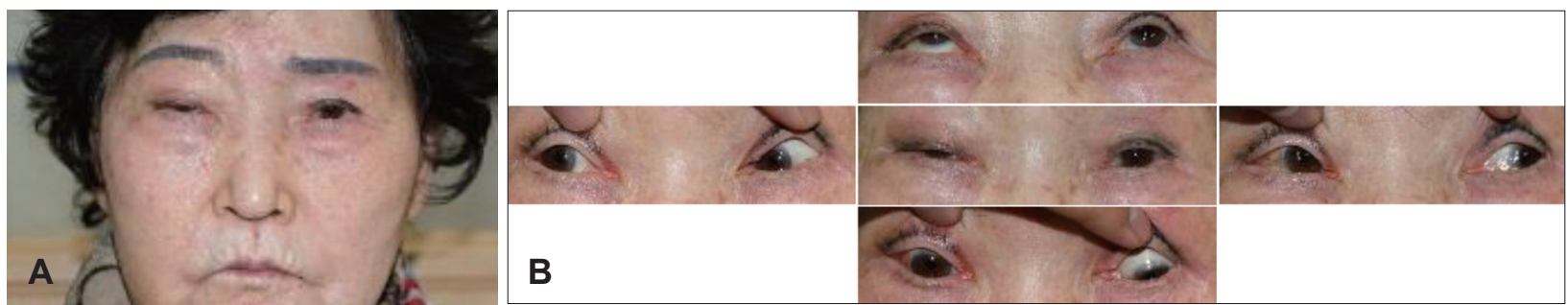

Fig. 1. The clinical photos of the patient. The preoperative photo shows swelling and ptosis in the right eye (A). Preoperative eyeball position. Extraocular movement motion test shows right eyelid ptosis and limitation of right eyeball movement, including adduction and down gaze (B).
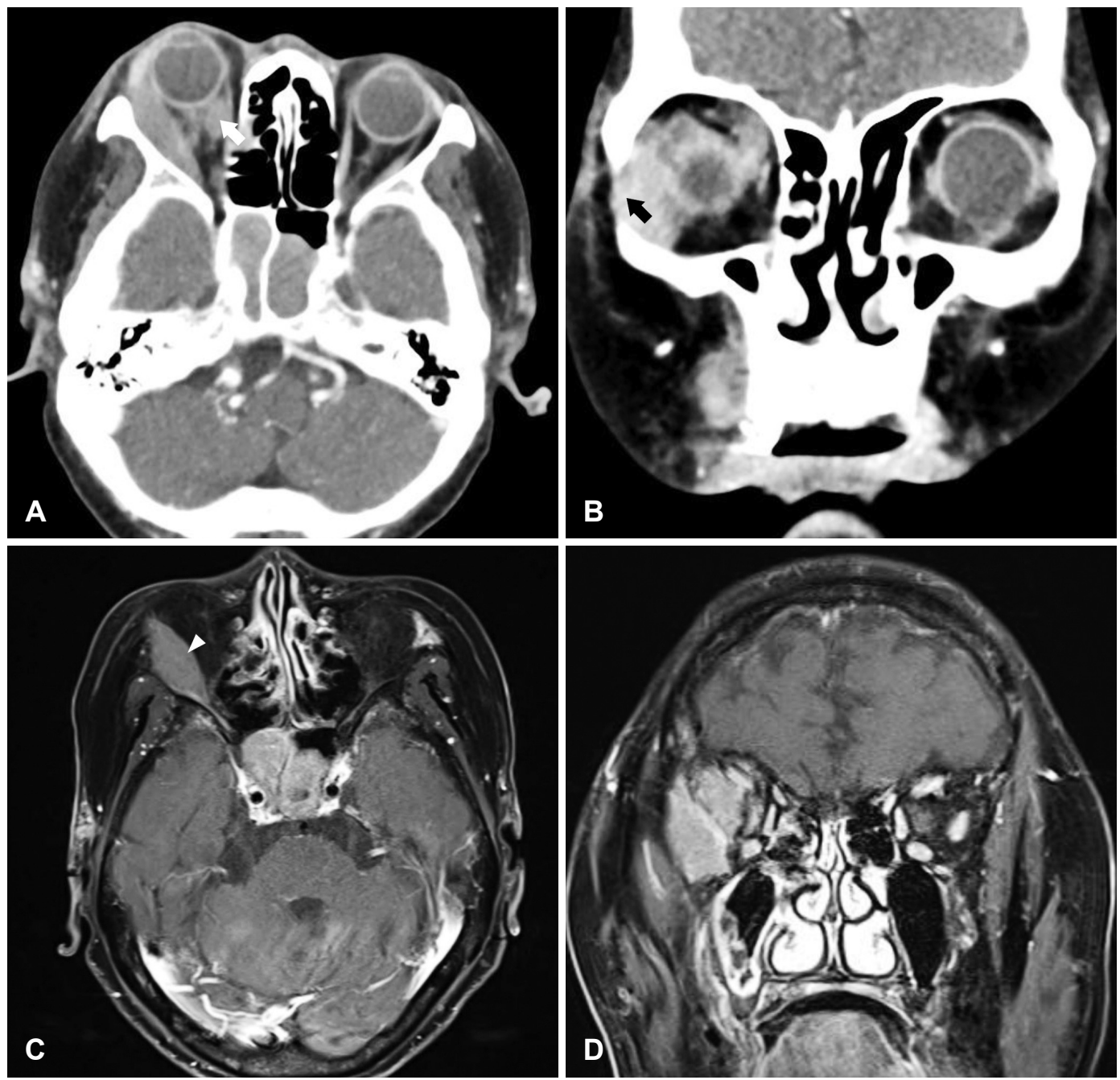

Fig. 2. Preoperative contrast-enhanced $C T$ scans $(A, B)$ and gadolinium-enhanced $M R$ images $(C, D)$ of the paranasal sinuses. Axial $C T$ scan shows multiple homogenous soft tissue density mass in right orbit with extracornal space (white arrow), and mass occupying both sphenoid sinuses (A). Coronal view shows bony erosion (black arrow) of the right lateral orbital wall (B). Axial MR image shows severe enlargement of lateral rectus muscle (arrowhead), and mass occupying both sphenoid sinuses (about $3.7 \mathrm{~cm}$ ) with expansion of the right sphenoid sinus (C). Coronal view shows multiple well-enhanced mass in the right orbit (about $3.8 \mathrm{~cm})(\mathrm{D})$. 
직검사를 계획하였다. 접형동의 종양과 안와의 종양이 동일한 병변인지 확인이 필요하였고, 안과와 병행하여 수술적 조직검 사를 시행하였다. 결막접근법 및 외안각절개술을 통해 안와의 종괴를 확인하여 조직검사를 시행하였으며, 부비동 내시경 수 술을 통해 우측 접형동 절개술을 시행한 이후 접형동 내의 종 물을 확인하여 조직검사를 시행하였다(Fig. 3). 수술 중 시행 한 동결절편검사에서 안와 및 접형동 내의 종물 모두 림프종 소견을 보였으며, 조직병리검사에서 소포 구조 및 이를 구성
하는 중심모세포와 중심세포가 관찰되었고, $\mathrm{B}$ 세포 표지자인 단클론성 항체 CD20을 사용한 면역조직화학 염색에서 양성 을 보였다. 추가적으로 실시한 면역조직화학 염색에서 Bcl-6 에 양성, $\mathrm{Bcl}-2, \mathrm{CD}$ 10에 강한 양성을 보였으며 Ki-67 labelling index가 60\%로 확인되었고 CD3, CD5, Cyclin D1, TdT, $\mathrm{SOX} 11, \mathrm{CD} 21$ 에는 음성을 보여 이 결과들을 종합하여 소포 성 림프종으로 최종 진단되었다(Fig. 4). 전신 전이 유무 및 병기 결정을 위해 시행한 복부 및 흥부 전산화단층촬영에서
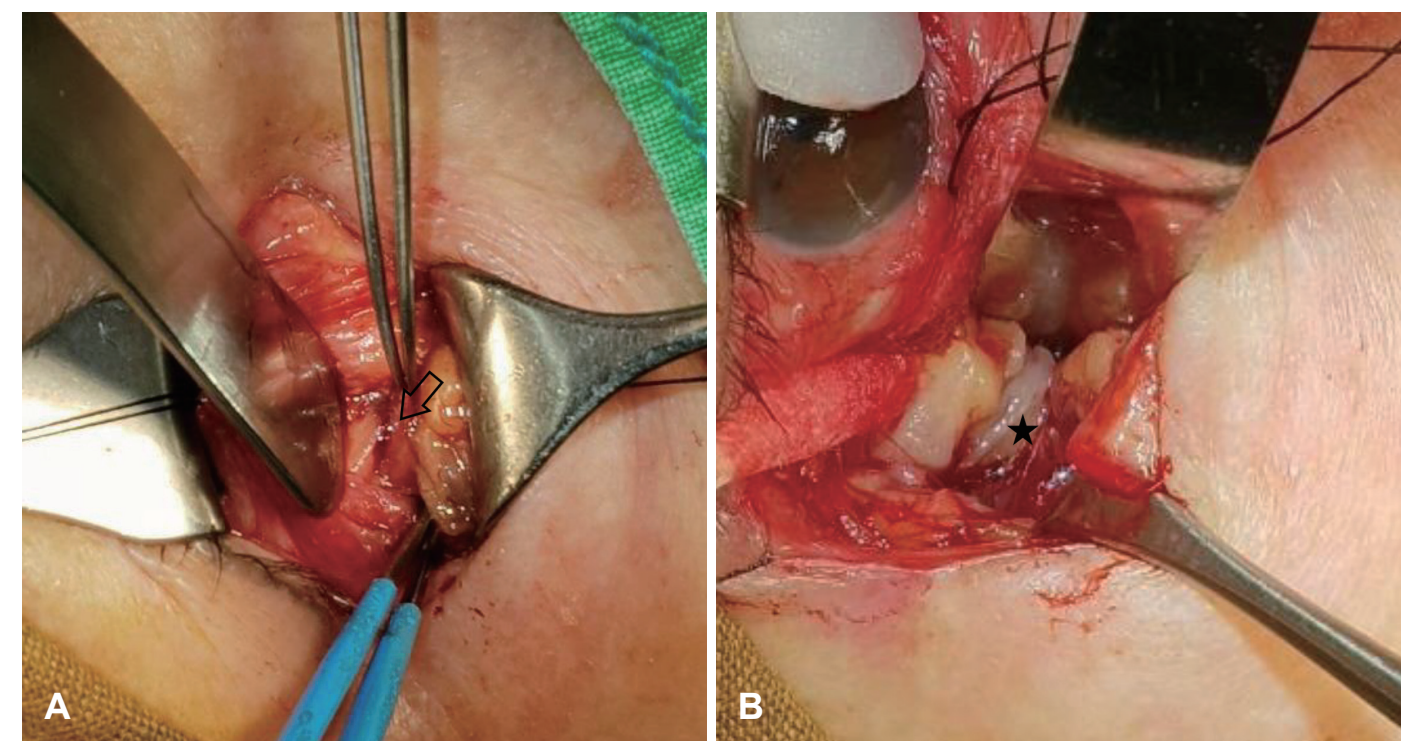

Fig. 3. Intraoperative findings. The conjunctival approach was done and the inferior rectus muscle (arrow) was exposed (A). Lateral canthotomy was done, and the inferior rectus muscle was retracted. A gray-colored tumor was exposed (star), and a biopsy was done (B).
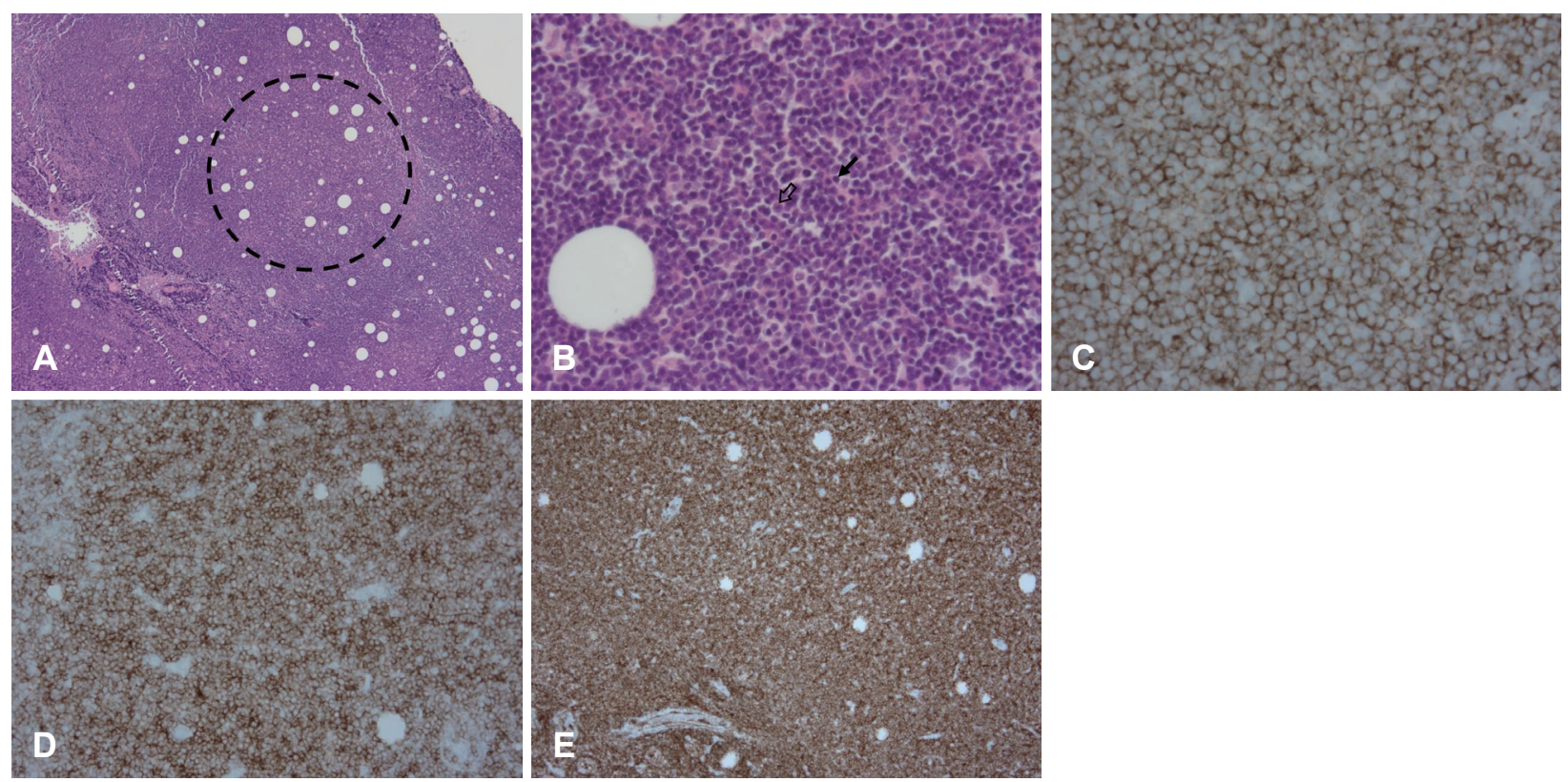

Fig. 4. Histopathologic features of follicular lymphoma. Vague follicular structures are noted (H\&E stain, $\times 40)(A)$. Follicles are composed of centroblasts (open arrow, large vesicular nucleus) and some centrocytes (closed arrow, small convoluted nucleus) present between centroblasts (H\&E stain, $\times 400)(B)$. Tumor cells are positive for CD20 (IHC staining, $\times 400)(C)$. Follicles are strongly positive for CD10 $(\mathrm{IHC}$ staining, $\times 200)$ and Bcl-2 (IHC staining, $\times 200)(D, E)$. H\&E stain: hematoxylin and eosin staining, IHC: immunohistochemical. 
특이소견은 없었으나, 양전자단층촬영 및 골 스캔 검사에서 양측 위 팔뼈, 우측 쇄골뼈, 흥골병 및 대퇴골 근위부의 골수 전이가 의심되는 소견이 있었다(Fig. 5). 또한 양측 골반뼈에 서 골수검사를 각각 시행하였으며, 우측 골반뼈에서 시행한 골수검사에서 림프종 침윤이 확인되었다.

우측 안와 및 접형동에서 발생하여 골수까지 침범한 Ann Arbor Stage IV의 소포성 림프종으로 최종 진단 후 5차례의 면역항암요법(rituximab, bendamustine)을 실시하였다. 치 료 시작 2 개월 후 시행한 안과적 검사에서 우안의 안검하수 및 운동장애는 호전을 보였으며 양안 교정시력은 우안 0.8 , 좌안 0.4 로 측정되어 시력 회복을 기대하였으나 치료 시작 6 개월 후
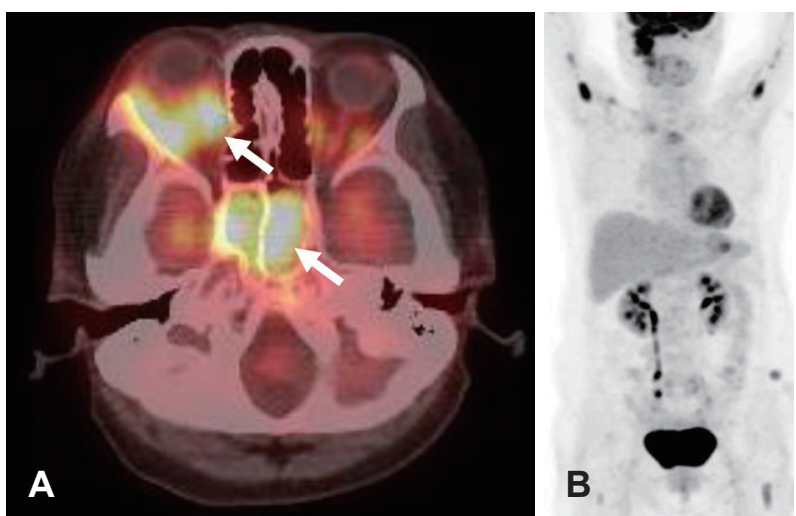

Fig. 5. Post-operative PET-CT images. It shows FDG uptake in the right orbit, sphenoid sinus (arrows) (A). It suggests multiple distant metastases with FDG uptake in both humerus, right clavicle, manubrium, and both proximal femur (B). FDG: fluorodeoxyglucose.
다시 우안 교정시력이 안전수동으로 악화되었다. 우안의 유리 체 혼탁 및 전방의 축농 소견이 보여 본원 안과에서 내인성 안구내염을 의심하에 유리체강내 항생제주입술[vancomycin $(1.0 \mathrm{mg} / 0.1 \mathrm{~mL})$, ceftazidime $(2.0 \mathrm{mg} / 0.1 \mathrm{~mL})]$ 을 실시하였 고 moxifloxacin을 1 시간 간격으로 점안하도록 하였으나 이 후 시력 회복은 관찰되지 않았다. 치료 후 4개월째 시행한 자 기공명영상에서 접형동의 종괴는 확인되지 않았으며 우측 안 와 종양의 크기가 감소한 것을 확인하였다. 그러나 함께 시행 한 양전자단층촬영상 다발성 원격전이 및 그 크기의 증가가 확인되어 이후 3 차례의 복합항암요법(doxorubicin, cyclophosphamide, vincristine, prednisolone)과 추가적으로 2차 례의 복함항암요법(ifosfamide, etoposide, carboplatin)을 실 시하였으나 별다른 반응이 없었으며, 치료 후 6 개월째 시행한 양전자단층촬영상 기존에 확인되던 전이성 암종의 크기가 증가된 소견이 보였고, 결국 7 개월 만에 환자는 사망하였다 (Fig. 6).

\section{고 찰}

악성 림프종이 림프절 외 림프조직에 발생하는 경우 주로 비호지킨 림프종이며, $\mathrm{B}$ 세포 림프종의 경우 비강 및 부비동 에서는 발생 빈도가 매우 낮다. ${ }^{3)}$ 접형동에서 발생한 비호지킨 림프종의 경우 극히 드물어 현재까지 해외에서 10예, 국내에 서 2예가 보고되었다. 해외의 경우 $\mathrm{T}$ 세포 림프종 1 예, 자연세
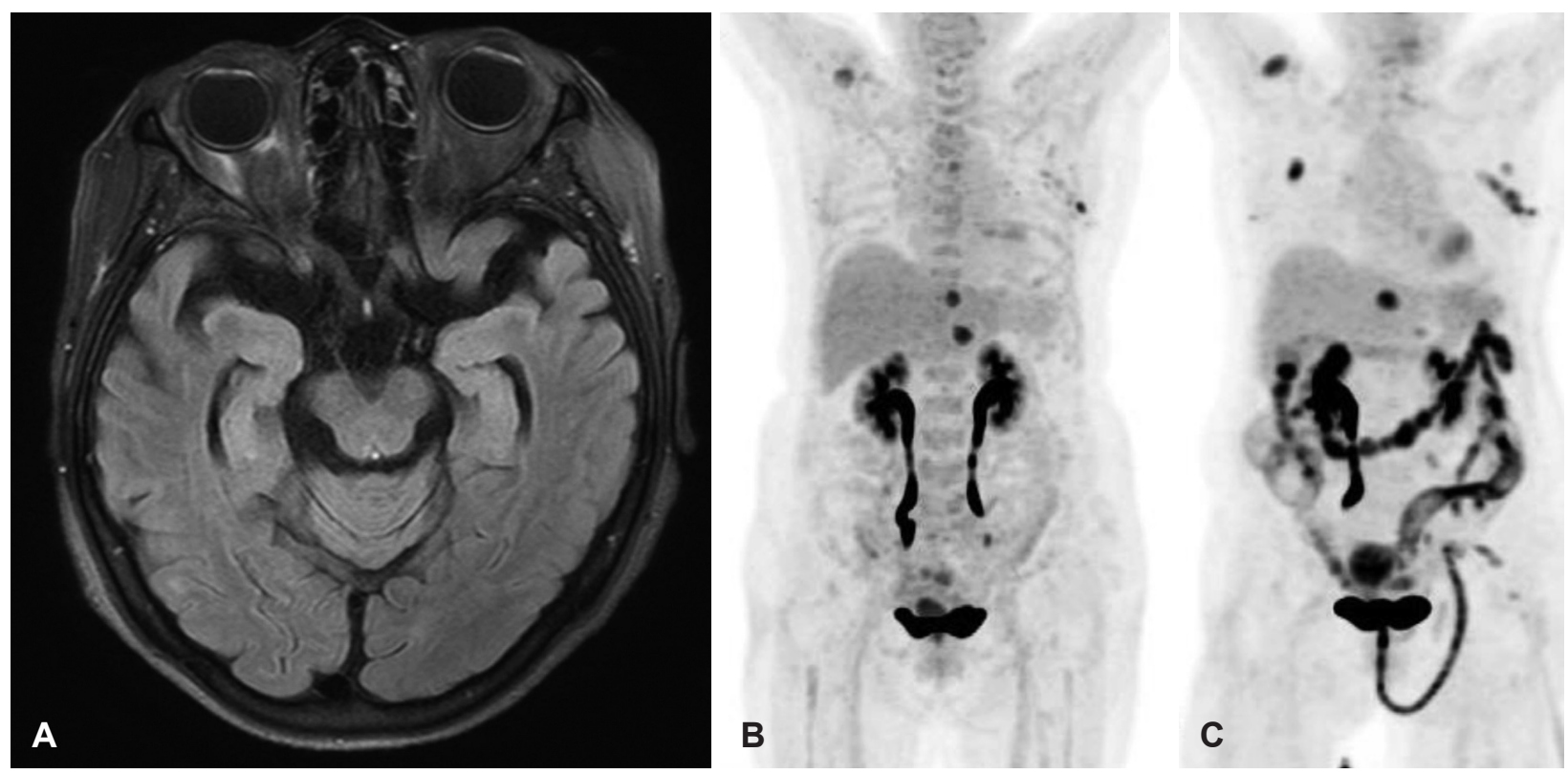

Fig. 6. Follow-up MR images and PET-CT. Axial view of the follow-up MR image after four months shows no evidence of residual tumor at both sphenoid sinuses and decreased size of mass at right orbit (A). Follow-up PET-CT after four months shows the increased size of metastasized cancer of anterior diaphragm and new metastasis to the omentum, both breast, left lower posterior pleura, right kidney, left neck, uterine cervix, right shoulder, upper posterior neck, posterior scalp, posterior back (T12 level) (B). Follow-up PET-CT after six months shows the increased size of metastasized cancer of both breast, anterior diaphragm, right kidney, and right scapula (C). 
포독성 $\mathrm{T}$ 세포 림프종 1 예를 제외하면 모두 미만성 거대 $\mathrm{B}$ 세 포 림프종으로 진단되었고 국내의 경우 미만성 거대 $\mathrm{B}$ 세포 림프종과 $\mathrm{T}$ 세포 림프종이 각각 1 예씩 보고되었으나 소포성 림프종이 접형동에서 발생한 경우는 전 세계적으로 보고된 바가 없다. ${ }^{2-7)}$

악성 림프종이 비강 및 부비동을 침범한 경우 초기증상은 비특이적이며, 증상이 있는 경우 비폐색, 비루, 후비루, 비출혈, 안면 부종 등이 나타날 수 있으며 전신 증상의 빈도는 낮다. ${ }^{8)}$ 이러한 비특이적 증상으로 인해 조기 진단이 힘들어 치료가 늦어지거나 종양이 다른 조직으로 침습되어 좋지 못한 결과 를 초래하기도 한다. ${ }^{9}$ 접형동을 침범한 경우 인접해 있는 해면 정맥동에 침범하여 동안신경, 외전신경, 삼차신경의 마비를 야기하기 때문에 두통, 복시, 삼차신경통이 주 증상으로 나타 나는 경우가 있으며, ${ }^{10)}$ 안와를 침범한 경우 안검 및 안와 주위 의 부종 또는 종괴, 안구돌출, 이물감, 안검하수, 시력장애, 복 시 및 안구 운동 제한 등의 증상이 나타날 수 있다. 본 증례의 경우 증상으로 안면 부종 및 통증, 우안 돌출, 시력장애를 호 소하였고, 안과적 검사에서 우안의 안검하수 및 안구운동장 애 소견을 보였다.

전산화단층촬영과 자기공명촬영은 각각 종양의 경계와 인 접 장기로의 침범여부를 파악할 수 있으나 병변의 초기에는 전산화단층촬영만으로는 골파괴와 국소 침윤 등의 종괴에 의 한 효과 외에 림프종의 특이적인 방사선학적인 소견이 없으므 로 염증성 질환과 감별진단이 어려울 수 있어 확진을 위해서 는 조직생검을 시행하는 것이 필수적이다. ${ }^{3)}$ 조직생검 시 감별 진단을 위해 항산균 및 진균 배양검사를 실시하며, 감별해야 할 질환으로는 결핵, 매독, 진균성 감염 등의 감염성 질환, 육 아종증 다발혈관염, 가성 종양 및 기타 종양성 질환 등이 있 다. ${ }^{2}$ 소포성 림프종의 조직병리검사 소견은 전형적으로 중심 세포(centrocyte)가 대다수를 차지하고 있고 중심모세포 (centroblast)들이 흩어져 있으며, 체세포 분열이 적고 변연부 (mantle zone)가 잘 발달되어 있지 않은 특징을 가지고 있 다. ${ }^{11)}$ 면역조직화학검사에서는 조직학적 병기에 따라 약간의 차이를 보이지만, 대부분에서 $\mathrm{Bcl}-2, \mathrm{CD} 10, \mathrm{CD} 20$ 에 양성을 보인다. ${ }^{12)}$ 본 증례의 경우에도 $\mathrm{Bcl}-2, \mathrm{CD} 10, \mathrm{CD} 20$ 에 양성을 보여 이를 확인할 수 있었다.

부비동에 발생한 소포성 림프종은 매우 드물어 확립된 치 료법은 없으나 일반적인 소포성 림프종의 치료는 병기, 원발 부위 이외의 장기 침범 여부, 분류, 환자의 전신상태에 따라 방 사선 치료, 항암화학요법, 방사선 치료와 항암화학요법의 병 행요법을 시행할 수 있다. ${ }^{12)}$ Ann Arbor Stage IA 또는 IIA의 제한된 병기에서는 증상 유무에 따라 방사선 치료를 시행할 수 있으며 B증상이 있거나 Ann Arbor Stage III 이상의 진행
된 병기에서는 복합항암요법이 기본적인 치료법으로 되어 있 고, 그 외에도 면역요법과 면역항암요법, 방사선면역요법과 같 은 다양한 전신적 치료 방법들을 고려해 볼 수 있다. Rituximab, cyclophosphamide, vincristine, prednisone(RCVP), rituximab, cyclophosphamide, doxorubicin, vincrinstine, prednisone $(\mathrm{R}-\mathrm{CHOP})$, rituximab, bendamustine (RB) 등이 일반적으로 사용되고 있으며, 본 증례에서도 $\mathrm{RB}$ 를 초기 치료로 시행하였다. 치료 후 완전 관해 혹은 부분 관 해를 달성한 경우 ${ }^{90} Y \operatorname{ttrium}\left({ }^{90} \mathrm{Y}\right)$ 표지 ibritumomab tiuxetan 과 방사선 치료를 이용한 강화요법을 시행하거나 rituximab 을 이용한 유지요법을 시행하여 progression-free survival 을 개선시킬 수 있다는 보고가 있으나 본 증례에서는 관해를 달성하지 못하였다. ${ }^{13)}$ 수술은 제거 가능한 국소 병변에 국한 되어 시행하거나 진단을 위해 제한적으로 시행하는 경우가 있 으며 다른 치료법의 보조적인 방법으로만 행해진다. ${ }^{12)}$

비강 및 부비동에 발생한 악성 림프종의 예후는 5년 생존 율이 $52 \%$ 정도로, 생존율과 연관되는 가장 중요한 예후인자 는 임상적 병기, 조직학적 분화도와 환자의 나이다. ${ }^{14)}$ 일반적 인 소포성 림프종의 경우 50 75\%에서 완전 관해율을 보이며 완전 반응을 보인 환자의 $20 \%$ 이상이 10 년 이상 관해 유지를 보이는 것으로 알려져 있다. ${ }^{12)}$ 저등급 소포성 림프종의 경우 평균 생존율이 18 년 이상인 것으로 보고되고 있으며, 증상이 있는 진행된 병기의 소포성 림프종의 경우도 면역항암요법 시 행 후 5년 생존율이 $90 \%$ 이상인 것으로 보고되고 있다. ${ }^{15)}$ 접 형동에 발생한 소포성 림프종의 경우 국내외에서 보고된 바 없어 예후에 관하여 알려진 것은 없으나, 본 증례의 경우 치료 에 반응이 없었으며 치료 후 7개월 만에 환자가 사망하여 일 반적인 소포성 림프종에 비해 예후가 나쁜 것으로 생각된다.

\section{Acknowledgments}

None.

\section{Author Contribution}

Conceptualization: Seong Kook Park. Data curation: Chanhyeon Park. Formal analysis: Chanhyeon Park. Investigation: Chanhyeon Park. Methodology: Seong Kook Park, Chanhyeon Park. Project administration: Seong Kook Park, Chanhyeon Park. Resources: Dong Hoo Lee, Ha Young Park. Software: Dong Hoo Lee. Supervision: Seong Kook Park. Validation: Chanhyeon Park. Visualization: Chanhyeon Park. Writing — original draft: Chanhyeon Park. Writing — review \& editing: Seong Kook Park

\section{ORCID}

Seong Kook Park https://orcid.org/0000-0003-3903-8412

\section{REFERENCES}

1) Plancarte F, López-Guillermo A, Arenillas L, Montoto S, Giné E, Muntañola A, et al. Follicular lymphoma in early stages: High risk 
of relapse and usefulness of the Follicular Lymphoma International Prognostic Index to predict the outcome of patients. Eur J Haematol 2006;76(1):58-63.

2) Cho EY, Lee JD, Kim MG, Kim MG. A T-cell lymphoma of sphenoid sinus extended to suprasellar area accompanying with acute visual loss. Korean J Otolaryngol 2003;46(11):984-9.

3) Jin SG, Jin KS, Oh JH, Kim BG. A case of diffuse large B-cell lymphoma of sinonasal tract with acute visual disturbance. Korean J Otorhinolaryngol-Head Neck Surg 2014;57(4):266-9.

4) Park YM, Cho JH, Cho JY, Huh JS, Ahn JY. Non-Hodgkin's lymphoma of the sphenoid sinus presenting as isolated oculomotor nerve palsy. World J Surg Oncol 2007;5:86.

5) Ye H, Gong Z, Yang W, Dai Y. Primary non-Hodgkin lymphoma of the sphenoid sinus with visual disturbance: A report of two cases. Oncol Lett 2016;11(6):4252-4.

6) Wang Q, Zhou SH, Chai L. B-cell malignant non-Hodgkin's lymphoma of the sphenoid sinus cavity: A case report and brief review of the literature. Ann Otolaryngol Rhinol 2014;1(2):1010.

7) Mao X, Jin L, Zhu B, Cui H, Yao M, Yao G. Primary sphenoidal sinus lymphoma with initial presentation as unilateral abducens nerve palsy symptom. Case Rep Neurol Med 2018;2018:5305963.

8) Kwon SY, Choi KS, Kim YB, Park CH, Lee YW, Kim CA. NonHodgkin's lymphoma of the nose and paranasal sinuses. Korean J Otorhinolaryngol-Head Neck Surg 1996;39(12):2016-21.
9) Chan JK, Sin VC, Wong KF, Ng CS, Tsang WY, Chan CH, et al. Nonnasal lymphoma expressing the natural killer cell marker CD56: A clinicopathologic study of 49 cases of an uncommon aggressive neoplasm. Blood 1997;89(12):4501-13.

10) Esposito F, Kelly DF, Vinters HV, DeSalles AA, Sercarz J, Gorgulhos AA. Primary sphenoid sinus neoplasms: A report of four cases with common clinical presentation treated with transsphenoidal surgery and adjuvant therapies. J Neurooncol 2006;76(3):299-306.

11) Pecorari P, Melato M. Non-Hodgkin's lymphoma (NHL) of the oral cavity. Anticancer Res 1998;18(2B):1299-302.

12) Chae R, Lee JY, Lee JY, Lee SH. A case of recurred follicular lymphoma in sublingual gland after complete remission. Korean J Otorhinolaryngol-Head Neck Surg 2014;57(7):469-72.

13) Bello C, Zhang L, Naghashpour M. Follicular lymphoma: Current management and future directions. Cancer Control 2012;19(3):18795.

14) Logsdon MD, Ha CS, Kavadi VS, Cabanillas F, Hess MA, Cox JD. Lymphoma of the nasal cavity and paranasal sinuses: Improved outcome and altered prognostic factors with combined modality therapy. Cancer 1997;80(3):477-88.

15) Hübel K, Salles G, Marcus R, Zinzani PL, Dreyling M. New treatment options in advanced stage follicular lymphoma. Hemasphere 2018;2(6):e156. 